\title{
Global development of innovative financial services. Does family economic socialization influence investor behavior in real estate crowdfunding?
}

\author{
Renata Legenzova ${ }^{1, *}$, Gintarè Leckè ${ }^{1}$ \\ ${ }^{1}$ Vytautas Magnus University, Faculty of Economics and Management, S. Daukanto st. 28, Kaunas, \\ Lithuania
}

\begin{abstract}
Research background: Globalization, digitalization and growth of technological innovations trigger development of new financial services, such as real estate crowdfunding. Seeking better return opportunities individual investors often disregard neoclassical decision-making criteria, while behavioral factors, such as social influence, emotions, cognitive abilities are gaining importance. This paper addresses the role of family economics socialization as a complex process by which individuals acquire social skills, knowledge, behavior patterns needed to make investment decision by purposively or spontaneously interacting with their family members.

Purpose of the article is to assess if and how family economic socialization impacts on investor behavior in real estate crowdfunding.

Methods: Research data was collected through an online survey of Lithuanian real estate crowdfunding investors. Then structural equation modeling technique was employed to investigate the impact of family economic socialization on behavior of real estate crowdfunding investors.

Findings \& Value added: Findings revealed that majority of real estate crowdfunding investors make bounded rationality investment decisions. Family, as one of the main agents of the economic socialization, does not ensure rationality of the crowdfunding decision-making process. Purposive family economic socialization has no impact on the behavior of investors with bounded rationality, yet it has a significant impact on behavior of rational family members. Spontaneous family economic socialization proved to have a positive and significant impact on the behavior of investors with bounded rationality. Taking into consideration rapid global development of innovative financial services market, such results might be a troubling signal for the product developers and market regulators.
\end{abstract}

Keywords: economic socialization; real estate crowdfunding; investor behavior; behavioral economic; bounded rationality.

*Corresponding author: renata.legenzova@vdu.lt 
JEL Classification: Z13; D12; G41

\section{Introduction}

In the $21^{\text {st }}$ century financial system is undergoing substantial changes. Global access to financial markets, digitalization and the growth of technological innovations are changing financial system and new financial services, such as real estate crowdfunding, are emerging. New innovative financial services feature exceptional characteristics, such as higher risk than traditional financial services, higher complexity, lower level or non-existent regulation, use of new technologies to develop and provide such services, and non-traditional suppliers. Such characteristics of innovative financial services alternate the investment decision-making process, therefore investor behavior is also changing. Neoclassical determinants of investor behavior in real estate crowdfunding platforms, such as income, interest rates, return and risk, decrease their significance. On the other hand, behavioral determinants, such as social influence, emotions, cognitive abilities, are gaining greater importance. Also, due to the global trends in financial system digitalization, rapid transformation and the exceptional characteristics of innovative financial services, such as real estate crowdfunding, investors are constantly forced to learn new information, skills and form their attitudes towards real estate crowdfunding. Financial literacy, financial education, cognitive abilities or social networks play an important role in making real estate crowdfunding investment decisions. For this reason, the phenomenon of economic socialization becomes even more relevant and important to understand how investors in real estate crowdfunding behave. Also, quite a little is known about investor behavior in innovative financial services and its determinants (Goa and Foak, 2015; Kovarova-Simecek and Aubram, 2018; Santos et al., 2021). According to process of economic socialization, socialization agent, for example, family, friends, school, media, interact with investor of real estate crowdfunding platforms and convey attitudes, motives, skills, information that is important and necessary for financial decision-making. Therefore, the aim of this article is to assess if and how family economic socialization impacts investor behavior of real estate crowdfunding, as one of the recently emerged innovative financial services.

\subsection{Economic socialization}

Economic socialization is the process by which an individual acquires the social skills needed to function effectively in an economic environment (Webley and Nyhus, 2013). According to this definition, an individual interacts with economic socialization agent, for example, family, friends, colleagues, school, media and create economic knowledge, skills and patterns of behavior that are important for economic decision making. Based on Copur and Gutter (2019) family is main and most influential agent of economic socialization, therefore, the article focuses only on family economic socialization. The way the individual learns specific economic subjects depends upon sociodemographic attributes such as age, life cycle position, social class, and upon psychological attributes such as knowledge, attitudes, motives, and skills that are already learned (Gudmunson, Ray and Xiao,2016). Economic socialization is interaction process during which individual are learning to become members of economic system. The main aspects of economic socialization - the economic environment surrounding the individual and the impact on individual economic decisions.

The phenomenon of economic socialization is not widely studied in the recent scientific literature. This is possibly due to the two main reasons. Firstly, based on the authors' (Bowles and Gintis, 2002; Psalidopoulos, 2015) research economic socialization can be described as a part of the models and theories of behavioral economics. In the seventies and eighties of $\mathrm{XX}$ a. the ideas of economic socialization were relevant, and more and more researchers 
analyzed this phenomenon, but in the $21^{\text {st }}$ century, there has been a marked decline in research of economic socialization. The decrease in research of economic socialization may have been determined by the fact that the mentioned phenomenon merged with the ideas of behavioral economics which have become particularly relevant in $21^{\text {st }}$ century. Secondly, the research field of economic socialization was divided into two research directions - financial socialization and consumer socialization. Financial socialization focuses on the formation of financial skills, knowledge, attitudes required for financial decision-making (Bowen, 2002). According to Ward, Klees and Wackman (1990) consumer socialization can be described as "process by which young people acquire skills, knowledge and attitudes relevant to their effective functioning as consumers in the marketplace." Although the phenomenon of economic socialization is not new, analyzed in the 20th century, it is not given enough attention for this phenomenon in the 21 st century.

In the center of economic socialization process - interaction between individual and agents of economic socialization. Interaction can occur in the several ways. According to De Gregorio and Sung (2010), Gudmundson et al., (2016) there are the main four ways of interaction between individual and agents of economic socialization - direct teaching (discussion, instruction/training), indirect teaching (modeling, observation), experiential learning and social interaction. Social interaction is the least analyzed way of interaction. Social interaction can be described as the strength of social ties (Luan et al., 2017) or recommendations (Anabo and Centeno, 2019). In our research, according to these four ways of interaction, we classify economic socialization into purposive (direct, indirect and experiential learning) and spontaneous (social interaction). Purposive economic socialization develops, modifies and complements economic knowledge, skills, attitudes which are needed for economic decision making. So, purposive economic socialization has indirect impact on behavior of decision making through economic knowledge, skills, attitudes that can be understood as mental economic socialization outcomes. Spontaneous economic socialization impact behavior of decision making immediately. So, spontaneous economic socialization has direct impact on behavior of decision making.

\subsection{Investor behavior in real estate crowdfunding}

Investor behavior in real estate crowdfunding is defined as a process how the "investor judge, predict, analyze and review the procedures for investment" of real estate crowdfunding decision making (Martin-Oliver and Salas-Fumas, 2010). This process also includes investor psychology, information gathering, defining and understanding, research and analysis. Investor behavior in real estate crowdfunding can be described as investment decision making process and it depends upon neoclassical and behavioral determinants.

According to neoclassical theories, all investors make rational decisions and seek to maximize their utility. The main neoclassical determinants of investor behavior - income, the amount of capital, risk and return (Fernandez-Curogedo, 2004). However, in the modern global economy these neoclassical assumptions are not quite right. Also, due to exceptional characteristics of innovative financial services neoclassical models that determine income as one of the main determinants of investor behavior are not suitable for explaining the investment decision to such innovative financial services as real estate crowdfunding.

Behavioral models are more suitable for explaining current day decision making process by investor, because it based on a multiplicity of determinants for investor's behavior (D'Orlando and Sanfilippo, 2010). Behavioral economics focuses on the real investor with his cognitive abilities, psychological aspects and limited rationality. According to behavioral economic theories, an investor does not seek to maximize utility, he rather aims to satisfy his needs. Investors are neurologically minded including emotions, psychological aspects in the investment decision making process (Duxbury et al., 2020) Also, social environmental has 
impact on the investment in innovative financial services, including real estate crowdfunding decisions.

Real estate crowdfunding is an innovative financial service that distinguished by exceptional characteristics. Because of that, income, risk and return are not the main determinants that affect investor behavior. Social impact, financial knowledge, attitudes, psychological biases can have much more significant impact on investor behavior in real estate crowdfunding. Family economic socialization, as the concept combining all such determinants is the main object of this paper's analysis.

\section{Methods}

The main aim of this research is to assess if and how family economic socialization impacts investor behavior of real estate crowdfunding. For our analysis we have chosen Lithuania, a small open economy in the European union with growing economy, therefore investment potential, and open-minded investors interested in local and cross border innovative financial services.

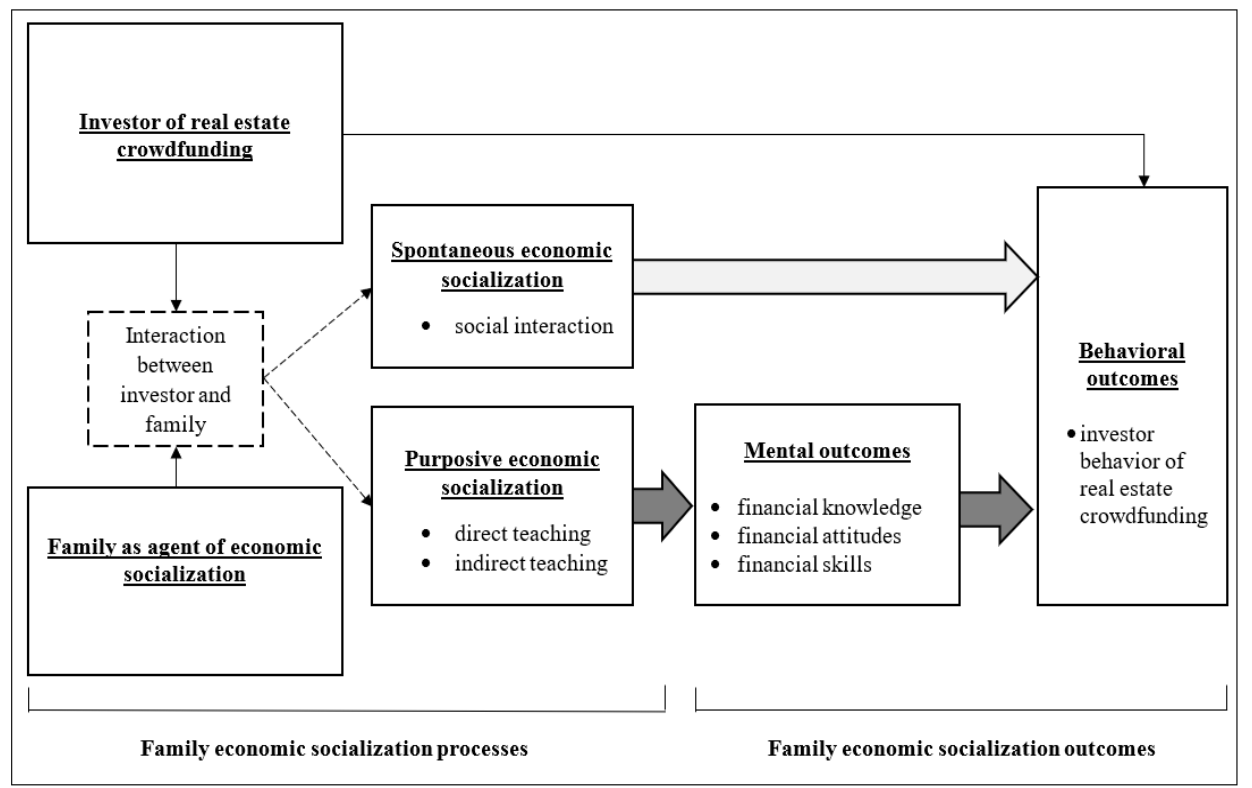

Figure 1. Conceptual research model

Source: created by authors according to De Gregorio and Sung (2010), Gudmundson et al. (2016).

The conceptual research model (as presented in the figure 1) is based on theoretical insights and built mainly based on De Gregorio and Sung (2010), Gudmundson et al. (2016). The conceptual model focuses only on the one agent of economic socialization (family), but the model is applicable to other agents of economic socialization as well. Our conceptual model consists of two main parts: family economic socialization processes and family economic socialization outcomes. Family economic socialization processes can be described as interaction between the investor of real estate crowdfunding and family as agent of economy socialization. Interaction can occur in four main ways, but in this research, attention is paid for three of them: social interaction, direct and indirect teaching. Based on ways of interaction, there can be disguised spontaneous and purposive economic socialization. Another part of our conceptual model is the outcomes of family economic socialization, 
which can be either mental or behavioral. In this research the mental outcomes are defined as financial knowledge, financial attitudes and financial skills of investors, while the behavioral outcomes - as either rational or bounded rationality behavior of real estate crowdfunding investors. Based on the conceptual research model, spontaneous economic socialization should have a direct impact on behavioral outcomes while purposive economic socialization should trigger an indirect impact on behavioral outcomes.

According to the proposed conceptual model the following research hypotheses were formulated:

H1: Investor of real estate crowdfunding make bounded rationality investment decisions.

According to Lefevre and Chapman (2017) investor do not always behave rational while making investment decisions and systematic irrational behavior - bounded rationality - is often observed. Based on this statement, H1 hypothesis is formed. The hypothesis is accepted or rejected based on two criteria: to what extent investors use return and risk criteria in real estate crowdfunding decision making and to what extent investors demonstrate behavioral biases.

H2: The influence of spontaneous family economic socialization on investor behavior in real estate crowdfunding is direct.

Usually, spontaneous family economic socialization happens without prior planning of its timing, content, therefore it is not held without any purpose to impact behavior. In this research spontaneous economic socialization is assessed as a social interaction (measured as social ties and economic recommendations). Based on assumptions of behavioral economics theories, we expect that social interactions should have a direct impact only on bounded rationality investor behavior, but it should not influence behavior of rational investors. Hypothesis H2 is tested using the Structural Equation Modeling (SEM) analysis.

H3: The influence of purposive family economic socialization on investor behavior in real estate crowdfunding is indirect.

We expect that purposive family economic socialization influences rational and bounded rationality investor behavior not directly, but through mental outcomes. Based on Kim and Torquati (2019) research results, purposive economic socialization has a direct impact on mental economic socialization outcomes and the latter directly affect investor behavior. Hypothesis H3 is tested using the Structural Equation Modeling (SEM) analysis.

Research methods. In our research we used a survey method to collect data on what is the level on rationality in investors decision and what is the family socialization influence on the investor's behavior. Then to analyze the research data and to test the hypothesis descriptive statistics was compiled and Structural Equation Model (SEM) was employed.

Data collection method. Research data was collected through an online survey. The research received an ethical clearance; and the questionnaire provided statements on the ethical use of collected data. The research questionnaire was developed by the authors adapting the evaluation scales used in previous research (Anabo and Centeno, 2019; Lusardi et al., 2014; Metzger and Fehr, 2017; Shim et al., 2015). The questionnaire consists of four sections and 24 questions. The $1^{\text {st }}$ section of the questionnaire contained a nominal scale and collected the demographic information of the investors of real estate crowdfunding. $2^{\text {nd }}, 3^{\text {rd }}$ and $4^{\text {th }}$ sections of research questionnaire contained a Likert scale ranging from 1-strongly disagree to 5 -strongly agree. In the $2^{\text {nd }}$ section collected information about rational and bounded rationality investor behavior of real estate crowdfunding. Rational investor behavior identified according to risk-return criteria scale of 9 items and bounded rationality behavior identified to five behavior biases. In the $3^{\text {rd }}$ section collected information about primary economic socialization outcomes (investors' financial knowledge scale of 4 items, financial attitudes scale of 2 items and financial skills scale of 3 items) and in the $4^{\text {th }}$ section collected information about family economic socialization techniques. Purposive family economic 
socialization was assessed based on family direct teaching (discussion) scale that consist of 4 items, family direct teaching (lessons) scale that consist of 4 items and family indirect teaching (modelling) scale that consist of 4 items. Spontaneous family economic socialization was assessed based on social interaction scale that consist of 3 items.

Data analysis methods. Firstly, the reliability of the collected data was performed. Cronbach's alpha was used to measure the reliability of the questionnaire. Factors with a Cronbach's alpha above 0.7 were considered as reliable (Aiken, 2002). Demographic information about the investor of real estate crowdfunding was summarized using the descriptive statistics. Structural Equation Modelling (SEM) analysis was performed to establish the causal relations between the constructs of the research model (Figure 1). Confirmatory factor analysis (CFA) was performed to evaluate the hypothesized measurement structure. Chi-square test $\left(\chi^{2)}\right.$, root mean square error of approximation (RMSEA) goodness-of-fit index (GFI), comparative fit index (CFI) and) is used to test the model fits (Lowry and Gaskin, 2014). Maximum likelihood estimation is applied to evaluate model parameters.

Research data. A total of 128 investors of real estate crowdfunding data were collected during the survey. There are four main real estate crowdfunding platforms in Lithuania. The exact number of real estate investors in Lithuania is not known, as some of the platforms are global and do not reveal how many investors are from Lithuania. To conduct this research we collaborated with one of the largest and global real estate crowdfunding platforms in Lithuania. Survey questionnaires were sent directly to investors of this platform and publicly distributed online.

Research limitations. Some questions answered by the respondents were about their interactions with the family (discussions, lessons, modelling), however the family members did not participate in the survey, so we were not able to verify the answers. I.e. the survey was based on the respondents' self-assessment. Also, we conducted cross-sectional research, and changes in variables over the time were included in the scope of this research.

\section{Results}

Reliability and descriptive statistics. Based on Cronbach's alpha, all questionnaire scales was reliable (Cronbach's alpha $>0,7)$. Considering the means, most of the respondents agreed with the statements measuring financial skills (4.20), financial knowledge (4.4), risk-return criteria (4.01), financial attitudes (3.98). However, the respondents unconvinced agreed with the statements measuring family economic socialization: family direst teaching (discussion) (3.34), social interaction (3.31), family indirect teaching (modelling) (3.23), family direct teaching (lessons) (3.08). According to results of Cronbach's alpha and means of variables, all scales were reliable and was used in research without correction.

Majority of the respondents were male $(69.5 \%)$ and while females constitute for the remaining $30.5 \%$. Most of the respondents were between the ages of 25 and 34 years $(34.5$ $\%)$ and the ages of 35 and 44 years (32\%). $24.3 \%$ of respondents earn net month salary that is higher than the average net salary in Lithuania - from 1001 to 1500 EUR per month and $17.2 \%$ of respondents - from 1501 to 2000 EUR per month. $17 \%$ of respondents get more than 3000 EUR per month net salary and 20.4 of respondents get less than 1000 EUR per month. $73.5 \%$ of respondents have a university degree $(32.9 \%$ - bachelor's degree, $39.9 \%$ - master's degree and $0.7 \%$ - PhD degree). $69.6 \%$ of respondents are employees while $22.5 \%$ of respondents are self-employed. Majority of respondents (79.6\%) live in one of the five biggest Lithuanian's cities. While analyzing the demographic characteristics of investors, it was questioned if respondents are related to the financial sector. The results showed that majority of respondents $(65.7 \%)$ are not related with finance sector. Based on demographic characteristics data of respondents a typical investor of real estate crowdfunding in 
Lithuanian was determined- it is a 25-34-year-old man, who gets higher than Lithuanian average net salary, is an employee, has master's degree, lives in one of the five biggest Lithuanian's cities and is not related to finance sector.

Investors' rationality assessment. The first questions which we were aiming to assess in our survey was how rational the Lithuanian investors are in making their real estate crowdfunding decisions The $2^{\text {nd }}$ section of questionnaire was dedicated to measure rational and bounded rationality investor behavior regarding real estate crowdfunding. In this study 9 risk and return criteria and 5 behavioral biases: herd behavior, status quo, familiarity, information novelty biases, overconfidence were assessed. Behavior was identified as being rational in the cases whereas investors made their investment decisions based on at least 5 out of 9 return and risk criteria and no behavioral biases were identified. The results revealed that $19.5 \%$ of respondents did not have any behavioral bias while making investment decisions, however while making investment decisions some of them did not consider more than 5 risk and return criteria used in the questionnaire. So, according to these results, just 18 $\%$ of respondents could be considered as rational investors in real estate crowdfunding. Behavior was identified as being bounded rationality in the cases whereas investor made their investment decisions based on at least one behavior biases. $80.47 \%$ of investors in real estate crowdfunding demonstrated at least one behavioral bias and was considered as investors with bounded rationality behavior. $42.19 \%$ of investors in real estate crowdfunding demonstrated just one behavioral bias while almost $4 \%$ of investors demonstrated all five behavioral biases. The most common behavioral bias in this research - familiarity. $74.2 \%$ of investors of real estate crowdfunding can be characterized by familiarity bias that means they invest just only to real estate crowdfunding platforms that they know, or it works in their country. $30.5 \%$ of investors of real estate crowdfunding are overconfidence and think that their investment performance is better than the market average. $16.4 \%$ of investors tend to make investment decisions based on the decisions of friends or family members. $13.3 \%$ of investors are not inclined to make investment changes even if higher returns are offered. The least behavioral bias in the research - information novelty. Just $10.2 \%$ of investors evaluates only the most up-to-date information when making investment decisions. Based on behavioral biases and evaluated risk-return criteria while making investment decisions, in this research. H1 hypothesis is accepted - investors of real estate crowdfunding make bounded rationality investment decisions.

Assessment of direct and indirect impact. Before forming a structural equation model of research, initial CFA model of latent variable constructs (purposive and spontaneous family economic socialization) was performed. The initial CFA model construct was adequate in achieving the acceptable model fit for further SEM analysis $\left(\chi^{2}=6.410\right.$, RMSEA $=0.01, \mathrm{GFI}=0.951, \mathrm{CFI}=0.948)$. The significant factor loadings (discussions $=0.647$, lessons $=0.513$, modeling $=0.764$, social interacton_1 $=0.954$, social interaction_2 $=0.877$, social interaction $3=0.295$ ) demonstrated adequate validity of the constructs. In addition, the results of the composite reliability $(\mathrm{CR})$ also demonstrated adequate internal consistency of the measured constructs (purposive family economic socialization $\mathrm{CR}=0.68$ and spontaneous family economic socialization $\mathrm{CR}=0.78$ ). The structural equation model of economic socialization's impact on investors behavior in real estate crowdfunding is presented in figure 2 . 


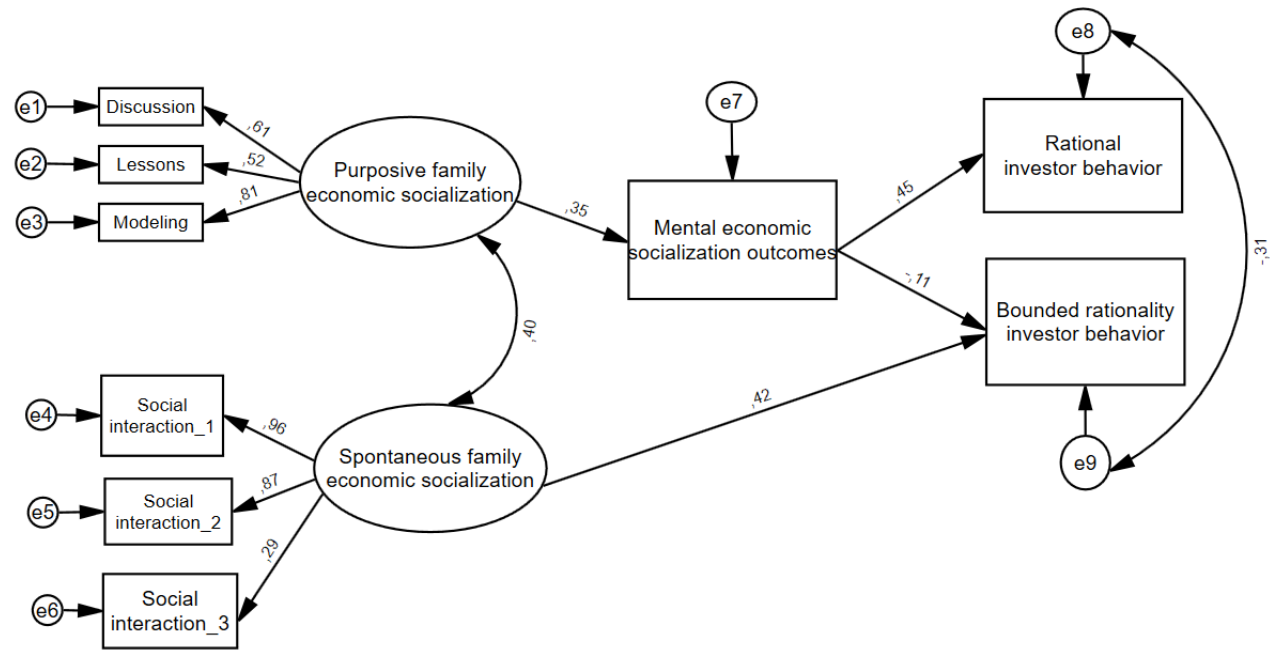

Figure 2. Structural model of the economic socialization

Source: created by authors

The baseline model (as presented in figure 2 ) fitted the data modestly well $\left(\chi^{2}=41.39\right.$, RMSEA $=0.07, \mathrm{GFI}=0.938, \mathrm{CFI}=0.947)$. Purposive family economic socialization had indirect impact on investor behavior of real estate crowdfunding. It also significantly improved the mental outcomes of economic socialization $(\beta=0.35, \mathrm{p}<0.01)$ while the mental outcomes significantly improved rationality of investor behavior $(\beta=0.45, p<0.01)$. However, the mental outcomes had no significant impact on bounded rationality investor behavior of real estate crowdfunding. The total standardized indirect impact of purposive family economic socialization on the rational investor behavior was 0.16 ( $\mathrm{p}<0.01$ ). Modelling, as an indicator of the purposive family economic socialization, was the strongest indicator of purposive family economic socialization $(\beta=0.81, \mathrm{p}<0.01)$ while lessons was the weakest indicator of purposive family economic socialization $(\beta=0.81, p<0.01)$. All three indicators of the purposive family economic socialization were statistically significant. Spontaneous family economic socialization had significant impact on bounded rationality investor behavior $(\beta=0.42, \mathrm{p}<0.01)$. The impact of spontaneous family economic socialization on investor behavior in real estate crowdfunding was stronger than the one of the purposive family economic socialization. Recommendations was a stronger indicator of spontaneous family economic socialization (social interaction_1 $\beta=0.96, p<0.01$, social interaction_2 $\beta=0.87, \mathrm{p}<0.01)$ than family social ties $(\beta=0.29, \mathrm{p}<0.05)$.

According to the quantitative results of SEM analysis, H2 hypothesis is accepted - the impact of spontaneous family economic socialization on bounded rationality behavior was direct. Family financial recommendations about real estate crowdfunding and social ties with family impacted bounded rationality behavior of real estate crowdfunding investors. These results showed that after receiving a recommendation from family members investor tends to make bounded rationality investment decisions. Also, investors, who have stronger social ties with the family, tend to make bounded rationality investment decisions.

H3 hypothesis is partly accepted - the impact of purposive family economic socialization on rational behavior of real estate crowdfunding investors was statistically significant and indirect through mental economic socialization outcomes, while the impact on the investors' bounded rationality behavior was statistically insignificant. Even though financial discussions and lessons and financial behavior modelling in family improve rational behavior of real estate crowdfunding investors, this impact was not so strong as was the impact of 
spontaneous economic socialization on the investor's bounded rationality behavior. These results revealed that family economic socialization does not bring a significant level of rationality while making real estate crowdfunding decisions.

\section{Conclusions and Discussions}

Globalization, digitization and the growth of technological innovations influences the emergence of new financial services which, among all other things, alter existing risk and return based decision making criteria and shift behavioral, individual level factors to the forefront of decision making process. Based on the example of Lithuania, this research was aiming to assess if and how family economic socialization impacts investor behavior of real estate crowdfunding.

Our findings identified that a typical investor of real estate crowdfunding is a 25-34-yearold man with master's degree, who works in a company, gets higher than average net month salary and lives in one of the five biggest Lithuanian's cities. The collected data also confirmed that a vast majority $(80.47 \%)$ of investors of real estate crowdfunding make bounded rationality investment decisions which made it relevant to further assess if and how family, as one of the most important socialization agents, is influencing their decision making.

To assess the direct and indirect impact of family economic socialization on the behavior of real estate crowdfunding investors we employed structural equation model (SEM) analysis. The results of SEM analysis indicate that family economic socialization has a significant impact on the behavior of real estate crowdfunding investors. Purposive economic socialization has a significant indirect and positive impact on the behavior of rational investors of real estate crowdfunding while spontaneous economic socialization has a significant direct and positive impact on the behavior of the investors with bounded rationality. The indirect impact of purposive family economic socialization on rational investors' behavior is weaker than the direct impact of the spontaneous family economic socialization on the bounded rationality investors' behavior. This could mean that financial recommendations given by the family trigger more irrational investment decisions than the ongoing family financial discussions, which, on contrary, led to rational investment decisions, related to real estate crowdfunding.

Indirect and positive impact of purposive family economic socialization on rational and responsible financial behavior also was identified in previous studies (Kim and Torquati, 2019; Santos et al., 2021; Shim et al., 2015). Zainudin et al. (2019) also found that purposive family economic socialization has indirect and positive impact on bounded rationality investor behavior. Gao and Fok (2015) reported that social interaction, used as a proxy for spontaneous family economic socialization, had a direct and positive impact on risky financial decisions. It had to be noted that previous studies mostly assessed the impact of economic socialization on the overall financial behavior of investors, while in our study we concentrated on real estate crowdfunding, as one of the innovative and globally available financial services. Also, to our knowledge, previous studies have questioned the influence of either purposive or spontaneous family economic socialization, while our research combined both types of socialization and brought more in depth assessment on how family influences innovative financial services related decisions.

\section{References}

1. Aiken, L. R. (2002). Psychological testing and assessment (11th ed.). Boston: Allyn and Bacon. 
2. Anabo, F. D., \& Centeno, D. G. (2019). Social Influence on Consumer Financial Product Preferences. Philippine Management Review, 26.

3. Bowen, C. F. (2002). Financial knowledge of teens and their parents. Financial Counseling and Planning, 13(2), 93-101.

4. Bowles, S., \& Gintis, H. (2002). Schooling in Capitalist America Revisited. Sociology of Education, 75(1), 1-18.

5. Copur, Z., \& Gutter, M. S. (2019). Economic, Sociological, and Psychological Factors of the Saving Behavior: Turkey Case. Journal of Family and Economic Issues, 40, 305322.

6. De Gregorio, F., \& Sung, J. (2010). Understanding attitudes toward and behaviors in response to product placement: A consumer socialization framework. Journal of advertising : official publication of the American Academy of Advertising, 39(1), 83-96.

7. D'Orlando, F., \& Sanfilippo, E. (2010). Behavioral Foundations for the Keynesian Consumption Function. Journal of Economic Psychology, 31(6), 1035-1046.

8. Duxbury, D., Gärling, T., Gamble, A., \& Klass, V. (2020). How emotions influence behavior in financial markets: a conceptual analysis and emotion-based account of buysell preferences. The European Journal of Finance, 26(14), 1417-1438.

9. Fernandez-Corugedo, E. (2004). Consumption theory in Handbooks from Centre for Central Banking Studies. Bank of England.

10. Gao, M., \& Fok, R. (2015). Demographics, family/social interaction, and household finance. Economics, 136(C), 194-196.

11. Gudmunson C. G., Ray S. K., \& Xiao J. J. (2016). Financial Socialization. In: J. Xiao (Ed.) Handbook of Consumer Finance Research. Springer, Cham.

12. Kim, J. H., \& Torquati, J. (2019). Are You Close with Your Parents? The Mediation Effects of Parent-Child Closeness on Young Adults' Financial Socialization Through Young Adults' Self-reported Responsibility. Journal of Family and Economic Issues, 42, 314-324.

13. Kovarova-Simecek, M., \& Aubram, T. (2018). Financial Literacy, Information Behavior, and Interest in Financial News in Austria. SSRN. https://ssrn.com/abstract=3156961

14. Lefevre, A., \& Chapman, M. (2017). Behavioural economics and financial consumer protection. OECD Working Papers on Finance, Insurance and Private Pensions, 42.

15. Lowry, P. B., \& Gaskin,, J. (2014). Partial Least Squares (PLS) Structural Equation Modeling (SEM) for Building and Testing Behavioral Causal Theory: When to Choose It and How to Use It. IEEE Transactions on Professional Communication, 57(2), 123-146.

16. Luan, J., Yao, Z., \& Bai, Y. (2017). How Social Ties Influence Consumer: Evidence from Event-Related Potentials. Plos One, 12(1).

17. Lusardi, A., Mitchell, O., \& Curto, V. (2014). Financial literacy and financial sophistication in the older population. Journal of Pension Economics and Finance, 13(4), 347-366.

18. Martin-Oliver, A., \& Salas-Fumás, V. (2010). I.T. Investment and Intangibles: Evidence from Banks. Review of Income and Wealth, 57, 513-535.

19. Metzger, B. A., \& Fehr, R. R. (2018). Measuring Financial Risk Attitude: How to Apply Both Regulatory and Scientific Criteria to Ensure Suitability. Journal of Behavioral Finance, 19(2), 221-234. 
20. Psalidopoulos, M. (2015). Interdisciplinary Economics. Kenneth E. Boulding's Engagement in the Sciences, by Wilfried Dolfsma and Stefan Kesting (eds.). The European Journal of the History of Economic Thought, 22(2), 338-339.

21. Santos, D. B., Mendes-Da-Silva, W., Norvilitis, J. M., Protin, P., \& Onusic, L. (2021). Parents Influence Responsible Credit Use in Young Adults: Empirical Evidence from the United States, France, and Brazil. Journal of family and economic issues, 1-16. Advance online publication.

22. Shim, S., Serido, J., Tang, C., \& Card, N. (2015). Socialization processes and pathways to healthy financial development for emerging young adults. Journal of Applied Developmental Psychology, 38, 29-38.

23. Ward, S., Klees, D. M., \& Wackman, D. B. (1990). Consumer Socialization Research: Content Analysis of Post-1980 Studies, and Some Implications For Future Work. Advances in Consumer Research, 17, 798-803.

24. Webley, P., \& Nyhus, E. K. (2013). Economic socialization, saving and assets in European young adults. Economics of Education Review, 33, 19-30.

25. Zainudin, R., Mahdzan, N.S. \& Yeap, M.-Y. (2019). Determinants of credit card misuse among Gen Y consumers in urban Malaysia. International Journal of Bank Marketing, 37(5), 1350-1370. 